\title{
津波被害を受けた鉄筋コンク DISASTER RESTORATION SURVEY リート造建築物の復旧状況調査 FOR REINFORCED CONCRETE BUILDINGS DAMAGED BY TSUNAMI
}

\author{
松川和人— $* 1$ 中埜良昭 — $* 2$ \\ キーワード : \\ 津波, 復旧, 解体
}

Keywords:

Tsunami, Restoration, Demolition

\section{Kazuto MATSUKAWA $-* 1 \quad$ Yoshiaki NAKANO - $* 2$}

In this report, results of field survey for tsunami-damaged reinforced concrete (RC) buildings are explained. The survey was carried out to study validity of an index to help building owners to judge the building shall be demolished or restored. The index describes the relative inundation heights, which is defined as the highest number of inundated stories divided by number of stories of building. From the results of the survey, it is found that the index will be helpful for the restoration/ demolish judgement of tsunami-damaged RC buildings.
1. はじめに

2011 年東北地方太平洋沖地震は、併発した津波により東北地方太 平洋沿岸部を中心として甚大な被害をもたらした。今般ほど多くの 建築物が津波により浸水被害を受けるという経験は近年では初めて のことであり、震災を受けて、津波外力に対する建築物の設計法に 関する研究など、その対策に向けた検討が数多く進められている。 一方で、浸水した建築物の継続使用の可否や復旧の困難さ／容易さ 等を判断する方法を整備することも、広い意味での防災対策として は非常に重要なことである。

津波による浸水を受けた鉄筋コンクリート造（以下 RC 造）建築物 の被害の特徴としては、概ね下記のようなものが挙げられよう。

(1)上部構造の構造被害は船舶等の衝突被害を除けば軽微

(2) 建築物内部に土砂や瓦礫が流入し、非構造材や設備等の損耗 や破壊が発生

（3）火災被害も場合によっては併発

2011 年の発災時には、こうした被害を評価し継続使用あるいは解 体等の判断を行うために参考となる技術資料が存在しなかったため、 少なからぬ混乱を生じた。すなわち、建築物の継続使用を行う上で は構造躯体の復旧と非構造材や設備等の復旧とを行う必要があるが、 後者に要するコストが前者のそれよりも大きくなるケースが多かっ たと想定され、直接的にコストを判定対象とはしていない被災度区 分判定基準 ${ }^{1)}$ などの資料を用いて継続使用可否の判断を行うことが 難しかった。著者らは、被災度区分判定基準（2001 年版）の改訂委 員会に所属し、津波被災建築物の継続使用可否を判断するための目 安に関する議論に参加してきた。本論文では、そこで議論された判 断目安の妥当性を、2011 年東北地方太平洋沖地震で津波被害を受け た建築物の復旧状況調查を行い個々の建築物になされた継続使用可 否判断の結果を分析することにより評価した。

\section{2. 復旧状況調査の概要}

復旧状況調查は、 2012 年 11 月 23 日〜 25 日、 2013 年 7 月 24 日〜
29 日、 2014 年 10 月 10 日〜 14 日において、著者らが所属する東京

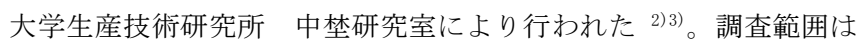
2011 年に同研究室にて被害調查を行った青森県三沢市〜福島県相 馬市の太平洋沿岸部である ${ }^{4)}$ 。調査対象建築物は文献 ${ }^{4)}$ に記載の 2011 年に調査された RC 造建築物がほとんどであるが、2014 年の調 查時には岩手県釜石市大町地区（ほぼ $300 \mathrm{~m}$ 四方の市街地）において 新たに RC 造建築物の全数調查を行っており ${ }^{3)}$ 、ここで調査された建 築物をはじめとして 2013 年以降新たに調査を行った建築物も含ん でいる。

調査項目は、(1)用途、(2)階数、(3)特筆すべき構造被害、(4)浸水深、 (5)最高浸水階、(6)復旧状況などである。それぞれの定義と分類方法 を以下で述べる。

(1)用途：文献 ${ }^{1)}$ の分類に従い、建築物の主たる用途を分類した。

(2)階数 : 建築物の主要な部分の階数を記録した。

(3)特筆すべき構造被害 : 2011 年調査報告書 ${ }^{4)}$ 及び調查時の記録、文 献 5)より、上部構造に特筆すべき構造被害が生じている場合はその 旨を記載した。転倒・局所破壊・中破（上部構造・基礎構造を対象 に文献 ${ }^{1)}$ に準じて評価した）以上の被害・火害が該当する。

(4)浸水深 : 2011 年調查報告書 ${ }^{4)}$ 、文献 ${ }^{5)}$ より、計測された浸水深を 記載した。当該建築物での浸水深の記録が無い場合、別の近接する 建築物で計測された值があればその值を採用した。

(5)最高浸水階：当該建築物中浸水した層のうち、最も高い位置にあ る階を記録した。最高浸水階の判断は、調査時の記録や写真により 最高浸水階を明確に特定可能であったものはその階を最高浸水深と して採用し、それ以外のものでは空ガラスの破損状況等から推定し たものも存在する。

(6)復旧状況 : まず 2012 年以降の復旧状況調查報告書 ${ }^{23)}$ 及び調查時 記録から、建築物を「残存」／「撤去」に分類した。「残存」は津波 被災建築物がその場に残存していれば、その状態を問わず「残存」 と分類した。「撤去」は、津波被災建築物がその場に残存していなけ れば「撤去」と分類した。また、その利用が再開されている建築物

\footnotetext{
東京大学生産技術研究所 助教・博士 (工学)

( T 153-8505 東京都目黒区駒場 4-6-1)

東京大学生産技術研究所 教授・工博
}

\footnotetext{
Research Assoc., Institute of Industrial Science, The Univ. of Tokyo, Ph. D

2 Prof., Institute of Industrial Science, The Univ. of Tokyo, Ph. D.
} 
については「継続使用されている」、そうでない建築物については「継 続使用されていない」と分類した。当然のことながら、「撤去」され た建築物はその寸べてが「継続使用されていない」に該当する。

加えて、写真 1 にその一例を示すように、調查時には個々の建築 物ごとに 2011 年調查時と同角度からの定点写真撮影を行っている。

\section{3. 調査結果}

\section{1 調査結果の概要}

本論文では津波による浸水被害を受けた建築物の継続使用可否に 関する現実的な判断目安を分析することを目的としているため、以 降の分析では調查対象建築物のうち「(3)特筆すべき構造被害」が生 じた建築物を除き、残った建築物を分析対象建築物とする。表 1 (次 頁）に分析対象建築物の全リス卜を示し、図 1 に分析対象建築物全 81 棟の (a) 用途別、 (b) 階数別の度数の内訳を示す。

\section{2 復旧状況}

図 2 に浸水レベルと「残存」及び「撤去」された建築物の度数の 関係を示した。また、同図には全分析対象建築物を母数とした「残 存」に該当する建築物の割合も併記している。ここで、前述の被災 度区分判定基準改訂委員会での議論から、被害に対する復旧可否の 判断には建築物の浸水延べ面積の大小が、土砂や瓦磎の流入に対す る清掃、破損した設備・建具などの更新などの復旧コストと相関し、 継続使用可否の判断に影響するであろうとの予測のもと、浸水階数 の建築物階数に対する比率を継続使用可否に関連付ける被害レベル の大きさを表す指標として用いた。本論文ではその最高浸水階／建 築物階数を $R_{n i}$ と定義し、同じく被災度区分判定基準改訂委員会で の議論から、その值を 0.5 未満、0.5 以上 1.0 以下、 1.0 と区分し、 浸水被害の大小を表すこととした。図 2 より、浸水レベル $R_{n i}$ が小 さいほじ、残存している建築物の割合が大きくなる傾向が見られ、 $R_{n i}$ が 0.5 未満の建築物のうち約 $90 \%$ 多残存していた。一方 $R_{n i}$ が大 きい建築物ほど解体され撤去される傾向が強く、 $R_{n i}$ が 0.5 以上 1.0 未満の建築物では $65 \% 、 R_{n i} 1.0$ の建築物ではその $30 \%$ 程度の建築物 しか残存していない。

続いて図 3 に、浸水レベル $R_{n i}$ とそれぞれ「継続使用されている」 「継続使用されていない」建築物の度数の関係を示した。なお、図 中には全分析対象建築物を母数とした「継続使用されている」建築 物の割合も併記している。同図より、 $R_{n i}$ が小さい建築物は継続使用 されている割合が高く、 $R_{n i} 0.5$ 未満の建築物ではその 9 割近くが継 続使用されている。一方で、 $R_{n i}$ が 0.5 以上 1.0 未満の建築物では $55 \%$ 程度、 $R_{n i} 1.0$ の建築物では $15 \%$ 程度と、その割合が低くなって いることから、浸水レベル $R_{n i}$ は建築物継続使用の現実的な可否を 判断するための目安となり得ると考えられる。

\section{4. 特徵的な被害とその継続使用状況}

\section{4. $1 R_{n i} 0.5$ 未満であったが継続使用されていない建築物の事例分析}

全体的な傾向は第 3 章で述べた通りであるが、ここでは $R_{n i}$ が 0.5 未満でありながらも継続使用されていなかった建築物（表 2) につ いて分析を行う。表 2 より、 $R_{n i} 0.5$ 未満かつ継続使用されていない 建築物は、そのすべてが学校建築物や庁舎などの防災拠点となる心゙ き公共建築物である。これらの建築物は、今後、地震時や津波襲来 時の避難所として利用されるべきものであり、また、政治的・行政

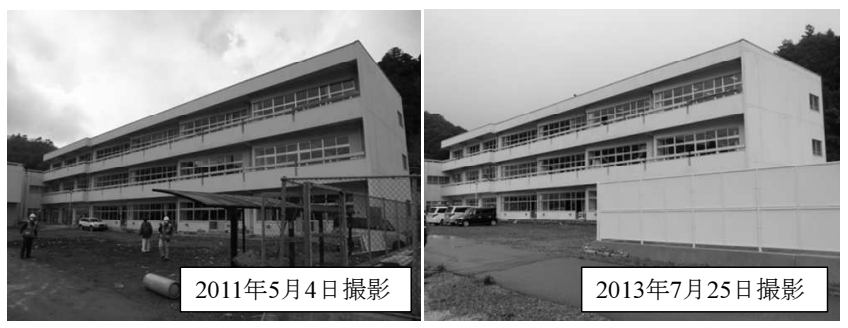

写真 1 定点写真撮影例

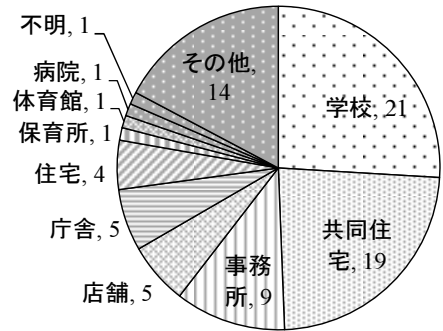

(a) 用途別

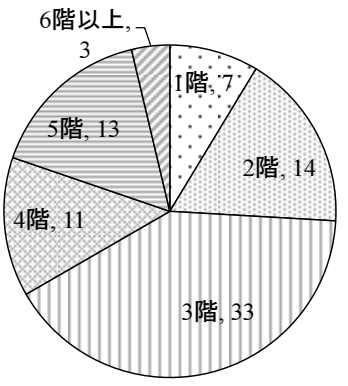

(b) 階数別
図 1 分析対象建築物の用途別・階数別の度数

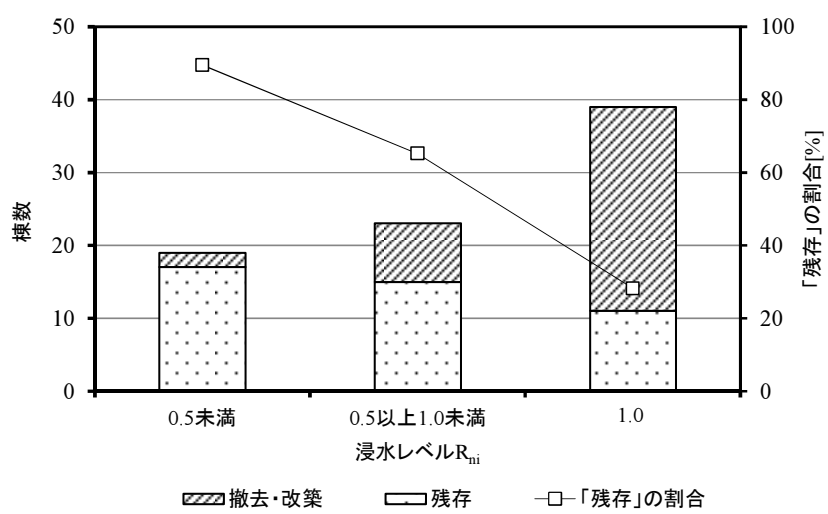

図 2 残存・撤去に該当する建築物の度数と浸水レベルの関係

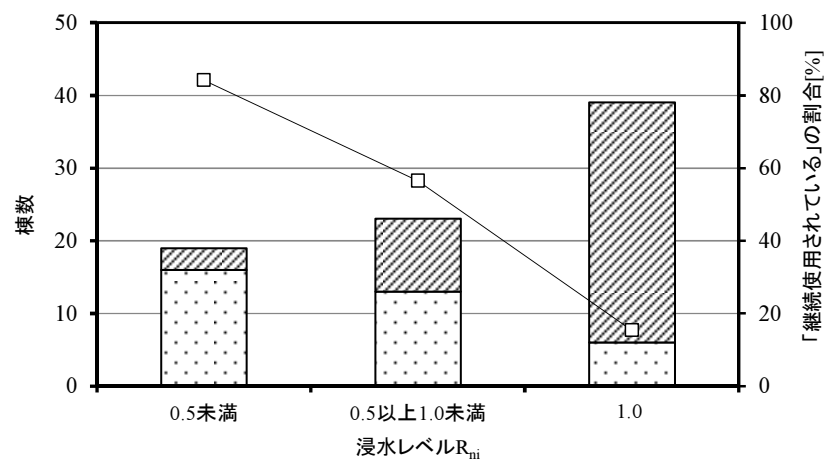

凹継続使用されていない こ継続使用されている -ロー「継続使用されている」の割合

図 3 建築物の継続使用状況と浸水レベルの関係

的な判断により都市計画全体の中に位置づけられるものでもあるた め、建築物として継続使用可能であったとしても、津波浸水域から 移転すべきという被災建築物解体への動機付けがその他の民間建築 物よりも強かったものと推察される。尚、表 2 の中ではW 中学校の み現地でピロティ形式かつ屋上への避難機能を有する新校舎への改 築がなされているが、0 中学校、K 合同庁舎は、それぞれ津波危険区 域、災害危険区域に新たに自治体から指定された地域に立地してお り、かつ高台移転が予定されている。 
表 1 分析対象建築物リスト

\begin{tabular}{|c|c|c|c|c|c|c|c|c|}
\hline \multirow{2}{*}{ No. } & \multirow{2}{*}{ 分析対象 } & \multirow{2}{*}{ 用途 } & & & & 复旧状: & & \\
\hline & & & 階数 & 最高浸水階 & 残存 & 撤去 & 継続使用 & $R_{n i}$ \\
\hline 1 & Hフェリーターミナル & その他 & 2 & 1 & 0 & & 0 & 0.50 \\
\hline 2 & H警察署水上警備派出所 & 庁舎 & 2 & 1 & $0 *$ & & $0 *$ & 0.50 \\
\hline 3 & M団地一号棟 A棟 & 共同住宅 & 3 & 1 & 0 & & 0 & 0.33 \\
\hline 4 & M団地一号棟 B棟 & 共同住宅 & 3 & 1 & 0 & & 0 & 0.33 \\
\hline 5 & K漁港漁業集落排水処理施設 & その他 & 2 & 2 & 0 & & 0 & 1.00 \\
\hline 6 & O中学校 校舎 & 学校 & 3 & 1 & 0 & & & 0.33 \\
\hline 7 & T第一中学校 教室棟1 & 学校 & 2 & 1 & 0 & & $\mathrm{O}$ & 0.50 \\
\hline 8 & T第一中学校 教室棟2 & 学校 & 3 & 1 & 0 & & 0 & 0.33 \\
\hline 10 & 雇用促進住宅K宿舎 1 & 共同住宅 & 5 & 3 & & 0 & & 0.60 \\
\hline 11 & 雇用促進住宅K宿舎 2 & 共同住宅 & 5 & 3 & & 0 & & 0.60 \\
\hline 12 & 雇用促進住宅K宿舎 3 & 共同住宅 & 5 & 3 & & 0 & & 0.60 \\
\hline 13 & 雇用促進住宅K宿舎 4 & 共同住宅 & 5 & 3 & & 0 & & 0.60 \\
\hline 14 & K住宅 & 共同住宅 & 5 & 3 & & 0 & & 0.60 \\
\hline 15 & K市営住宅 & 共同住宅 & 3 & 3 & & 0 & & 1.00 \\
\hline 16 & T小学校 校舎棟 & 学校 & 3 & 3 & & 0 & & 1.00 \\
\hline 17 & U幼稚園 & 保育所 & 2 & 2 & & 0 & & 1.00 \\
\hline 18 & KH中学校 普通教室棟 & 学校 & 3 & 3 & & 0 & & 1.00 \\
\hline 19 & KH中学校 特別教室棟 & 学校 & 4 & 4 & & 0 & & 1.00 \\
\hline 21 & U小学校 普通教室棟(1)，8) & 学校 & 2 & 2 & & 0 & & 1.00 \\
\hline 22 & U小学校 普通教室棟(2)，(7) & 学校 & 3 & 3 & & 0 & & 1.00 \\
\hline 23 & U小学校 管理·特別教室棟 & 学校 & 3 & 3 & & 0 & & 1.00 \\
\hline 24 & K海員会館 & 事務所 & 4 & 3 & & 0 & & 0.75 \\
\hline 25 & 市営Kビル & 事務所 & 8 & 2 & 0 & & $\mathrm{O}$ & 0.25 \\
\hline 26 & K海上保安部 & 庁舎 & 4 & 2 & 0 & & 0 & 0.50 \\
\hline 27 & Kハイツ & 共同住宅 & 5 & 2 & 0 & & 0 & 0.40 \\
\hline 28 & KKビル & 店舗 & 2 & 2 & 0 & & 0 & 1.00 \\
\hline 29 & SK園 & 店舗 & 3 & 2 & 0 & & 0 & 0.67 \\
\hline 30 & Aビル & 事務所 & 3 & 2 & 0 & & 0 & 0.67 \\
\hline 31 & Tスポーツ & 店舗 & 3 & 2 & 0 & & 0 & 0.67 \\
\hline 32 & K保健福祉センター & 病院 & 8 & 2 & 0 & & 0 & 0.25 \\
\hline 33 & O3丁目 住居 & 住宅 & 2 & 2 & 0 & & 0 & 1.00 \\
\hline 34 & Aハイツ & 共同住宅 & 4 & 2 & 0 & & 0 & 0.50 \\
\hline 35 & O3丁目 商業ビル & 店舗 & 3 & 2 & 0 & & 0 & 0.67 \\
\hline 36 & M第一ビル & その他 & 4 & 2 & 0 & & 0 & 0.50 \\
\hline 37 & Sブロードネット & その他 & 3 & 2 & 0 & & 0 & 0.67 \\
\hline 38 & M第二ビル & その他 & 5 & 2 & 0 & & 0 & 0.40 \\
\hline 39 & T旅館 & その他 & 3 & 2 & 0 & & 0 & 0.67 \\
\hline 43 & OF小学校 特別教室棟1 & 学校 & 3 & 1 & 0 & & 0 & 0.33 \\
\hline 44 & OF小学校 特別教室棟2 & 学校 & 3 & 1 & 0 & & 0 & 0.33 \\
\hline 45 & OF小学校 管理教室棟1 & 学校 & 3 & 1 & 0 & & 0 & 0.33 \\
\hline 46 & OF小学校 管理教室棟2 & 学校 & 3 & 1 & 0 & & 0 & 0.33 \\
\hline 47 & A 生命 & 事務所 & 3 & 3 & & 0 & & 1.00 \\
\hline 48 & MY 生命 & 事務所 & 3 & 3 & $\mathrm{O}$ & & & 1.00 \\
\hline 49 & OFシルバー人材センター & 事務所 & 3 & 3 & & $\mathrm{O}$ & & 1.00 \\
\hline 50 & 土木事務所港務所 & 事務所 & 2 & 2 & & 0 & & 1.00 \\
\hline 51 & 土木事務所港務所隣のRC 平屋 & 不明 & 1 & 1 & 0 & & & 1.00 \\
\hline 52 & $S G$ 商会 & 店舗 & 2 & 2 & & 0 & & 1.00 \\
\hline 53 & 雇用促進住宅RT第2 宿舎 5 号棟(海側) & 共同住宅 & 5 & 5 & $\mathrm{O}$ & & & 1.00 \\
\hline 54 & 雇用促進住宅RT第2 宿舎 6 号棟 (陸側) & 共同住宅 & 5 & 5 & & 0 & & 1.00 \\
\hline 55 & TK高等学校 教室棟 & 学校 & 3 & 3 & & 0 & & 1.00 \\
\hline 56 & RC 造壁式7 階建て集合住宅·P.F & 共同住宅 & 3 & 3 & & 0 & & 1.00 \\
\hline 57 & RC 造7 階建て住宅 & 住宅 & 3 & 3 & & 0 & & 1.00 \\
\hline 58 & K合同庁舎(県) & 庁舎 & 5 & 2 & & 0 & & 0.40 \\
\hline 59 & K合同庁舎(国) & 庁舎 & 5 & 2 & $\mathrm{O}$ & & 0 & 0.40 \\
\hline 60 & 町営住宅(津波避難ビル) & 住宅 & 4 & 4 & & 0 & & 1.00 \\
\hline 61 & 防潮堤水門脇のRC 造平屋観測小屋 & その他 & 1 & 1 & 0 & & & 1.00 \\
\hline 62 & RC 造3 階建て集合住宅·3 棟のうち1棟 & 共同住宅 & 3 & 3 & & 0 & & 1.00 \\
\hline 63 & $\mathrm{RC}$ 造3 階建て集合住宅·3 棟のうち1棟 & 共同住宅 & 3 & 3 & & 0 & & 1.00 \\
\hline 64 & RC 造3 階建て集合住宅·3 棟のうち 1 棟 & 共同住宅 & 3 & 3 & & 0 & & 1.00 \\
\hline 65 & RC 造9 階建てMS 旅館 & その他 & 5 & 5 & & 0 & & 1.00 \\
\hline 66 & ON消防署 & 庁舎 & 2 & 2 & & 0 & & 1.00 \\
\hline 67 & RC 造8 階建て住宅 & 共同住宅 & 4 & 4 & & 0 & & 1.00 \\
\hline 68 & ON町商工会館 & 事務所 & 4 & 4 & & 0 & & 1.00 \\
\hline 69 & 市営M住宅 & 共同住宅 & 4 & 3 & & 0 & & 0.75 \\
\hline 70 & かんぽの宿M & その他 & 4 & 2 & 0 & & & 0.50 \\
\hline 71 & A小学校 & 学校 & 4 & 2 & 0 & & & 0.50 \\
\hline 72 & W中学校 校舎 & 学校 & 3 & 1 & & & & 0.33 \\
\hline 73 & W温泉鳥の海 & その他 & 5 & 2 & 0 & & 0 & 0.40 \\
\hline 74 & W小学校 校舎 & 学校 & 3 & 1 & 0 & & 0 & 0.33 \\
\hline 75 & WY第二小学校 & 学校 & 2 & 1 & & 0 & & 0.50 \\
\hline 76 & T RC6 階住宅 & 住宅 & 2 & 2 & & 0 & & 1.00 \\
\hline 77 & YN小学校 校舎 & 学校 & 2 & 2 & 0 & & & 1.00 \\
\hline 78 & Y浄化センター 管理棟 & その他 & 1 & 1 & 0 & & 0 & 1.00 \\
\hline 79 & Y浄化センターポンプ室 & その他 & 1 & 1 & 0 & & 0 & 1.00 \\
\hline 80 & Y浄化センター 污泥棟 & その他 & 3 & 1 & 0 & & 0 & 0.33 \\
\hline 81 & SH地方卸売市場 & その他 & 1 & 1 & $0 *$ & & $0 *$ & 1.00 \\
\hline
\end{tabular}

$※ 2013$ 年 7 月調査時の復旧状況である。それ以外は 2014 年 10 月調査時の復旧状況を示した。 


\section{4. $2 R_{n i} 1.0$ でありながら継続使用されている建築物の事例分析}

$R_{n i}$ が 1.0 でありながら継続使用されている建築物は計 6 棟である。 このうち, Y 浄化センターのポンプ室ならびに事務棟（表 1 中 No. 78,79$)$ は RC 造平屋建てであり、発災時にはほぼ水没したと考え られるが 2013 年調查時には復旧され継続使用されていた(図 4 (a))。 $\mathrm{K}$ 漁港漁業集落排水処理施設（表 1 中 No. 5) は、 RC 造 2 階建の排水 処理施設であり、津波により漂着したと思われるゴミが屋根面に多

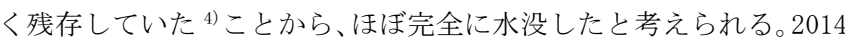
年調査時には復旧され継続使用されていた (図 $4(\mathrm{~b})$ )。

上記の建築物は、ほぼ全層が浸水したと考えられるため、 $R_{n i}$ の值 は 1.0 となる。しかしながら、これらの建築物は復旧され継続使用 がなされており、第 3 章で分析した全体の傾向からは説明できない 事例である。以下でその理由についての分析を試みる。

これらの建築物はその用途が排水処理施設であり、各地域の水道 系統の中に位置づけられているため他の建築物で代替寸る等の措置 を行うことは難しく、また、地域住民の衛生的な生活を支えるため の基盤的な建築物である。従って、津波により大きな被害を受けた からと言って撤去・解体・改築することは、地域住民の生活に長期 に渡って大きな影響を与えることが予想されるため、容易に行うこ とは出来ない。以上のような事情を勘案すれば、これらの建築物が $R_{n i} 1.0$ 相当の津波による浸水を受けたとしても、復旧され継続使用 が行われていることを説明することが出来る。実際に継続使用する /しないの判断を行う際には、その建築物が代替可能であるか等の 要素が優先される場合があることを端的に示唆する事例である。

尚、他にも KK ビル (No. 28)、03 丁目住居（No. 33）、SH 地方卸売 市場（No. 81）の 3 棟が $R_{n i}=1.0$ でありながら継続使用されていた。 これらの建築物が継続使用されるに至った意思決定のプロセスは明 らかでないが、KK ビル、03 丁目住居は比較的小規模な建築物であり、 加えて 2 階床レベルをわずかに越える程度の浸水レベルであったこ とから、継続使用へのコストが他の $R_{n i}=1.0$ の建築物と比較して小さ かった（清掃程度で復旧可能であったなど）可能性がある。SH 地方 卸売市場は土間床の典型的な市場建物であり、浸水被害を受けたと しても復旧は比較的容易であった可能性が高い。

\section{5. まとめ}

本論文では、津波により被災した鉄筋コンクリート造建築物の復 旧状況を調查し、建築物階数に対する相対的な浸水高さとの関係を 調查した。本研究で得られた知見を下記に示す。

- 最高浸水階/建築物階数の值である $R_{n i}$ と建築物の復旧状況は良 好に対応し、 $R_{n i}$ が 0.5 未満の建築物はその $90 \%$ が現地に残存してい た一方、 $R_{n i}$ が 1.0 の建築物はその $30 \%$ ぼしか残存していなかった。 - $R_{n i}$ と建築物の継続使用状況の関係を分析し、 $R_{n i}$ が 0.5 未満の建築 物はその $90 \%$ 近くが復旧され継続使用されていたが、 $R_{n i}$ が 1.0 の建 築物では 15\%ほどしか継続使用されていなかった。

・上記の検討で $R_{n i}$ が 0.5 未満でありながらも継続使用されていなか った建築物はその全てが公共建築物であり、これらの建築物は地震 後に避難所として利用される可能性が高いため、浸水域での継続使 用を行わない動機付けがその他の建築物よりも大きいと推察される。 ・ $R_{n i}$ が 1.0 の浸水被害を受けながらも復旧され継続使用がなされて いる建築物のうち浄化処理施設が 3 例存在した。この種の建築物は、

\section{表 $2 R_{n i} 0.5$ 未満でありながら継続使用されていなかった建築物}

\begin{tabular}{|c|c|c|c|c|c|c|}
\hline No. & 建築物名称 & 用途 & 階数 & $\begin{array}{c}\text { 最高 } \\
\text { 浸水階 }\end{array}$ & $R_{n i}$ & 備考 \\
\hline 6 & O中学校 校舎 & 学校 & 3 & 1 & 0.33 & \\
\hline 58 & K合同庁舎 (県) & 宁舎 & 5 & 2 & 0.40 & \\
\hline 72 & W中学校 校舎 & 学校 & 3 & 1 & 0.33 & ピロティ形式で改築 \\
\hline
\end{tabular}

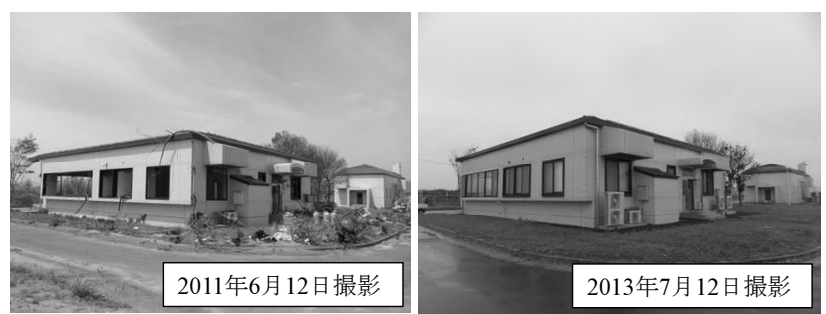

(a) Y 浄化センター事務棟

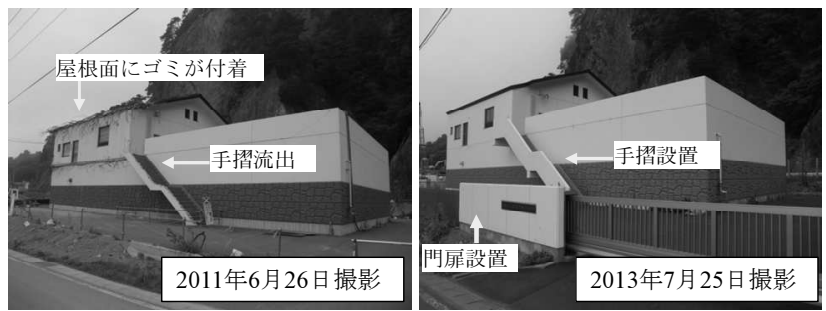

(b) K 漁港漁業集落排水処理施設

図4 $R_{n i} 1.0$ でありながら継続使用されていた建築物

住民の生活を支えるための重要な基盤施設で他の建築物で代替する ことが出来ない性質があり、建築物固有の性質が継続使用可否判断 に影響すると考えられる。

以上のことから、浸水のみの被害を受けた建築物のうち、 $R_{n i}$ が 0.5 未満であった建築物は特別な事情が無い限り継続使用可能であ り、 $R_{n i}$ が 1.0 であった建築物は現実的に継続使用が困難であると考 えられよう。 $R_{n i} 0.5$ 以上 1.0 未満の建築物は、継続使用される場合と されない場合がほぼ半数ずつであり、現状では判断が難しい。

\section{謝辞}

本研究は、(一財) 日本建築防災協会に設置された被災度区分判定 基準改訂委員会 $\mathrm{RC}$ 造部会（部会長：前田匡樹 東北大学教授）で の議論が端緒となっております。調査においては、東京大学生産技 術研究所 中埜研究室で実施いたしました。関係各位に感謝の意を 記します。また、調查に協力頂いた被災地の方々にも謝意を記すと 共に、一日も早い復興を祈念します。

\section{参考文献}

1）日本建築防災協会: 震災建築物の被災度区分判定基準および復旧 技術指針（2001 年改訂版），2001 年

2) 東京大学生産技術研究所 中埜研究室: 東北地方太平洋沖地震 復 旧復興状況調查報告書, 2013 年 10 月

3）東京大学生産技術研究所 中埜研究室: 津波避難施設の建設に資 する情報収集を目的とした東日本大震災被災地調查報告書, 2014 年 12 月

4）東京大学生産技術研究所 中埜研究室 : 2011 年 3 月 11 日東北地 方太平洋沖地震による建築物の地震被害および津波被害調查報告, 2012 年 3 月

5）日本建築学会:文教施設の耐震性能等に関寸る調査研究 報告書, 2012 年 3 月

[2015 年 2 月 2 日原稿受理 2015 年 3 月 31 日採用決定 $]$ 